\title{
High strength oil palm shell concrete beams reinforced with steel fibres
}

\author{
S. Poh-Yap $\bowtie$, U. Johnson-Alengaram, K. Hung-Mo, M. Zamin-Jumaat \\ Department of Civil Engineering, Faculty of Engineering, University of Malaya, (Kuala Lumpur, Malaysia) \\ $\triangle$ spyap@um.edu.my
}

\author{
Received 19 October 2016 \\ Accepted 1 March 2017 \\ Available on line 23 October 2017
}

\begin{abstract}
The utilization of lightweight oil palm shell to produce high strength lightweight sustainable material has led many researchers towards its commercialization as structural concrete. However, the low tensile strength of Oil Palm Shell Concrete (OPSC) has hindered its development. This study aims to enhance the mechanical properties and flexural behaviours of OPSC by the addition of steel fibres of up to $3 \%$ by volume, to produce oil palm shell fibre-reinforced concrete (OPSFRC). The experimental results showed that the steel fibres significantly enhanced the mechanical properties of OPSFRC. The highest compressive strength, splitting tensile and flexural strengths of 55,11.0 and $18.5 \mathrm{MPa}$, respectively, were achieved in the OPSFRC mix reinforced with 3\% steel fibres. In addition, the flexural beam testing on OPSFRC beams with $3 \%$ steel fibres showed that the steel fibre reinforcement up to $3 \%$ produced notable increments in the moment capacity and crack resistance of OPSFRC beams, but accompanied by reduction in the ductility.
\end{abstract}

KEYWORDS: Aggregate; concrete; Fibre-reinforcement; Flexural behaviour; Mechanical properties

Citation/Citar como: Poh-Yap, S.; Johnson Alengaram, U.; Hung-Mo, K.; Zamin-Jumaat, M. (2017) High strength oil palm shell concrete beams reinforced with steel fibres. Mater. Construcc. 67 [328], e142. http://dx.doi.org/10.3989/ mc.2017.11616

RESUMEN: Vigas de hormigón de alta resistencia con palma de aceite reforzados con fibras de acero. La utilización de cáscara ligera de palma de aceite para producir materiales duraderos y de alta resistencia ha llevado a muchos investigadores a su comercialización como hormigón estructural. Sin embargo, la baja resistencia a la tracción del hormigón de cáscara de palma de aceite (OPSC) ha obstaculizado su desarrollo. Este estudio tiene como objetivo mejorar las propiedades mecánicas y los comportamientos de flexión de OPSC mediante la adición de fibras de acero de hasta un 3\% en volumen, para producir hormigón armado de fibra de palma de aceite (OPSFRC). Los resultados experimentales mostraron que las fibras de acero mejoraron significativamente las propiedades mecánicas de OPSFRC. En la mezcla OPSFRC reforzada con fibras de acero al 3\% se obtuvieron las mayores resistencias a la compresión, resistencia a la tracción ya la flexión de 55, 11,0 y 18,5 MPa, respectivamente. Además, el ensayo de vigas flexibles en haces OPSFRC con fibras de acero al 3\% mostró que el refuerzo de fibra de acero hasta 3\% produjo incrementos notables en la capacidad momentánea y resistencia a la fisuración de los haces OPSFRC, pero acompañado de una reducción de la ductilidad.

PALABRAS CLAVE: Árido; Hormigón; Refuerzo de fibras; Resistencia a la flexión; Propiedades mecánicas

ORCID ID: S. Poh-Yap (http://orcid.org/0000-0002-2036-9740); U. Johson-Alengaram (http://orcid.org/0000-00019358-2975); K. Hung-Mo (http://orcid.org/0000-0001-5122-8839); M. Zamin-Jumaat (http://orcid.org/0000-00028783-1274)

Copyright: (C) 2017 CSIC. This is an open-access article distributed under the terms of the Creative Commons Attribution License (CC BY) Spain 3.0. 


\section{INTRODUCTION}

Lightweight concrete (LWC) has been used successfully for both structural and non-structural applications for many years. The structural applications of LWC are still increasing all around the world due to its benefits of good thermal insulation, better durability and reduction in self-weight of the structures $(1,2)$. The reduced density of LWC is important in the construction of high rise building, complex and long span structures especially in earthquake regions as it gives considerable cost savings, greater design flexibility and reduced cross-sectional area in members (1-3). Moreover, the increasing demand for concrete in the construction industry has resulted in the rapid depletion of the conventional concrete materials, such as granite aggregate and mining sand. Thus, the utilization of industrial and agricultural wastes to replace the conventional concrete materials imposes significant impact on the development of sustainable concrete. The wastes utilization process decreases the problems on scarcity of virgin materials, and reduces environmental pollution as well. Lightweight aggregates, such as slag, pulverized fuel ash, furnace clinker, expanded clay, pumice and oil palm shell (OPS) are among the materials commonly used to replace granite aggregate to produce LWC (4). From the above-mentioned lightweight aggregates, the utilization of OPS to replace the conventional coarse aggregate has gained considerable interest in developing regions, such as those in Southeast Asia and Africa. This is mainly attributed to the lightweight characteristic, high impact, and high abrasion resistance of OPS (2).

Despite the numerous advantages of LWC, the low tensile strength of LWC is limiting its structural applications $(1,2)$. Concrete with high tensile strength is desirable for the design of larger and longer structural members to arrest tensile cracking and to improve the tensile loading capacity. Furthermore, in the design of special structures, such as impact and blast resistant structural members, high tensile strength is mandatory (5). The flexural strength of OPSC in the range of about 3-5 $\mathrm{MPa}(6)$ is about $60 \%$ lower than normal weight concrete (NWC). Thus, enhancing the tensile strength of OPSC is essential to broaden its applications.

The incorporation of steel fibres in concrete is known to increase the toughness and ductility of concrete substantially, especially under tensile loading $(5,7,8)$. In this study, hooked end steel fibres with up to $3 \%$ (by volume) were added into OPSC in order to improve the low tensile strength of OPSC. The resulting new material will be oil palm shell fibre-reinforced concrete (OPSFRC). Mechanical properties and flexural behaviours of OPSC and OPSFRC beams were investigated and compared to evaluate the feasibility of OPSFRC in special structures subjected to impact, blast or earthquake.

\section{RESEARCH BACKGROUND}

The published research on Oil Palm Shell Concrete (OPSC) has shown that it could be produced within the density range of $1690-2020 \mathrm{~kg} / \mathrm{m}^{3}$ and with a compressive strength of up to $45 \mathrm{MPa}(6,9)$. Moreover, the long-term strength of the OPSC was investigated by Mannan and Ganapathy (10) who reported that there was no deterioration in the compressive strength up to 365 days. Meanwhile, there are limited studies on the flexural performance of OPSC reinforced concrete $(11,12)$. These investigations reported that OPSC beams showed comparable flexural capacities than NWC but with better ductility behaviour. OPSC beams exhibited considerable amount of cracks but the deflections fell within the allowable deflection limit in both the $\mathrm{ACI}$ and $\mathrm{BS}$ codes.

Meanwhile past studies on fibre-reinforced concrete reported significant enhancement of the mechanical properties, cracking resistance and durability compared to the conventional concrete $(3,7,8,13-19)$. The other reported advantages of steel fibres in concrete include improving toughness (19), ductility (20), flexural behaviours (21) and impact and blast resistance (5). The recent studies showed that the addition of fibres, particularly steel fibres by up to $1 \%$ enhanced the flexural strength and impact resistance of OPSC by $30 \%$ and 36 fold, respectively (22-24). However, the tensile strength of the OPSC with $1 \%$ steel fibre was found to be well below the expected strength of $10 \mathrm{MPa}$ to resist high impact and blast loading (5).

Thus, to combine the advantages of the OPS and steel fibres, OPSFRC is studied in this research to widen the potential application of the OPSFRC for structural members subjected to impact and blast loading. Moreover, there are limited reports on flexural behaviours of fibre-reinforced LWC. This is mainly due to the vast diversity of fibre types and geometries available which limits the comparative studies on flexural behaviours $(20,25)$. The studies on flexural behaviours of fibre-reinforced LWC becomes more complicated with different types of lightweight aggregate involved. From the past literature, the effect of fibres on the flexural performances of reinforced concrete beams showed a few common benefits by the incorporation of steel fibres, including reduced brittleness, enhanced crack resistance and moment capacity $(21,26-28)$. However, Meda, Minelli \& Plizzari (29) had demonstrated that the fibre reinforcement can lead to a reduction in the ductility of reinforced concrete beams; while Qian \& Indubhushan (26) and Wang \& Belarbi (28) reported that steel fibres increased the displacement of beams at failure. The complexity then lies on the diverged 
(a)

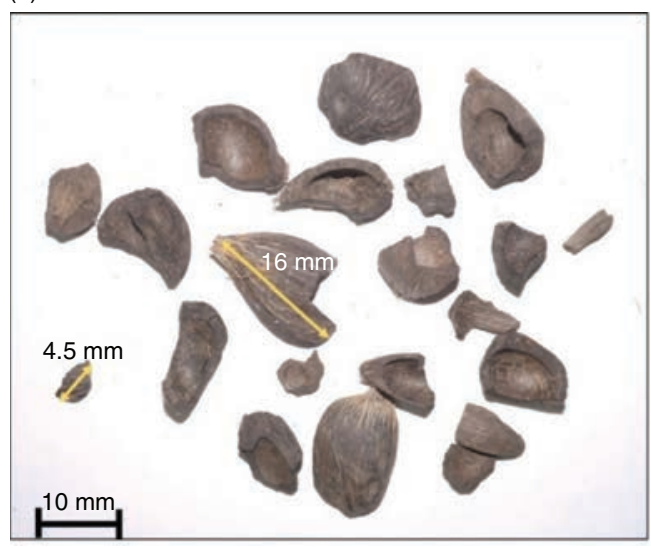

(b)

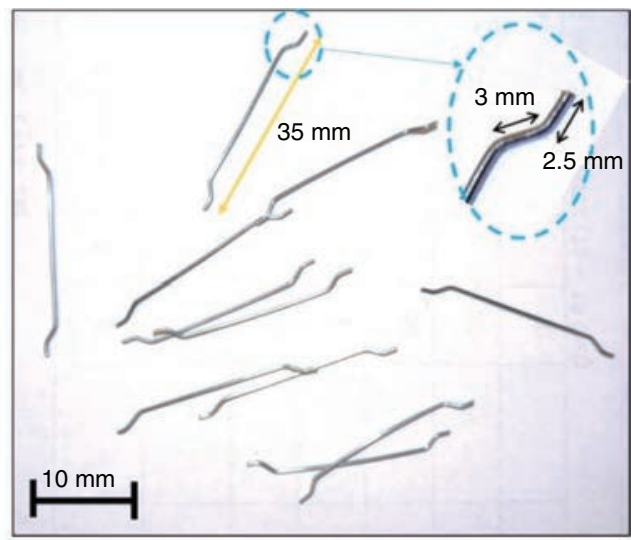

FIGURE 1. (a) OPS of diverse sizes used in the mix proportions and (b) Steel fibres.

observations on the flexural ductility of fibrereinforced concrete beams in past reports.

\section{MATERIALS AND METHODS}

\subsection{Materials}

Type 1 Ordinary Portland cement with a Blaine specific surface area and specific gravity of 3450 $\mathrm{cm}^{2} / \mathrm{g}$ and 3.13 , respectively was used. Silica fume of $10 \%$ cement weight was added as a supplementary cementitious material.

For the coarse aggregate, OPS collected from a local oil palm factory was used as a full replacement of conventional coarse aggregates. Fig. 1 shows the diverse sizes of OPS with concave and convex surfaces; the physical properties of OPS are given in Table 1. The low bulk density, aggregate impact value and Los Angeles abrasion value are the important characteristics of OPS that make it a valuable waste material for producing LWC with high energy absorption capacity. The OPS used in the preparation of OPSFRC was in the saturated surface-dry (SSD) condition to prevent the OPS from absorbing the effective water content for hydration. Before the mixing, the OPS are sieved to remove the OPS sized smaller than 5 $\mathrm{mm}$ and the OPS ranges from $5-16 \mathrm{~mm}$ are used in the mixing. Mining sand with a specific gravity and fineness modulus of 2.65 and 2.7, respectively, was used as fine aggregate.

Meanwhile, potable water $(\mathrm{pH}=6.5)$ was used in both mixing and curing processes. A polycarboxylatebased superplasticiser (Glenium Ace 388) supplied by BASF Malaysia of $0.8 \%$ cement weight was used to enhance the workability of the fresh concrete mixes.

In order to produce the OPSFRC, hooked-end steel fibres of aspect ratio of 65 were added into the OPSC mixes, as shown in Figure 1(b). The length and diameter of the fibres were $35 \mathrm{~mm}$ and 0.55 $\mathrm{mm}$, respectively. Specific gravity, tensile strength
TABLE 1. Physical properties of OPS

\begin{tabular}{lc}
\hline Physical properties & OPS \\
\hline Maximum size, mm & 16 \\
Aggregate Impact Value (AIV), \% & 2.11 \\
Los Angeles (LA) abrasion value, \% & 5 \\
Compacted bulk density, $\mathrm{kg} / \mathrm{m}^{3}$ & 635 \\
24-hour water absorption, $\%$ & 24 \\
Fineness modulus & 6.41 \\
Specific gravity (SSD) & 1.37 \\
Flakiness index, \% & 41 \\
Elongation index, \% & 59 \\
\hline
\end{tabular}

and modulus of elasticity of the steel fibres used were $7.9,1100 \mathrm{MPa}$, and $205 \mathrm{GPa}$, respectively.

\subsection{Specimen preparation and testing}

The mix proportions of all the OPSC and OPSFRC mixes are shown in Table 2. The variable investigated in this research is the steel fibre volume. Compared to the previous study (22), the cement content was slightly increased to $530 \mathrm{~kg} / \mathrm{m}^{3}$ to provide higher amount of cement paste for the formation of fibre-cement matrix bond.

For each mix proportion, $100 \mathrm{~mm}$ cubes, 100 $\phi \times 200 \mathrm{~mm}$ cylinders, $150 \phi \times 300 \mathrm{~mm}$ cylinders, and $100 \times 100 \times 500 \mathrm{~mm}$ prisms were prepared for compressive strength (BS EN 12390:2009), splitting tensile strength (ASTM C496/C496M-11), modulus of elasticity/Poisson's ratio (ASTM C469-10), and flexural strength (ASTM C78-10, respectively. After the removal of the specimens from the moulds, these specimens were cured in water until the age of testing. All tests were conducted at the age of 28 days.

Meanwhile, for the reinforced concrete beam test, six beams were designed and prepared as under-reinforced concrete beams in accordance to the BS 8110 to produce flexural mode of failure for the HT0, HT10 and HT30 mixes. Two beams were 
TABLe 2. Mix proportions

\begin{tabular}{lcccccc}
\hline Mix designations & Cement $\left(\mathbf{k g} / \mathbf{m}^{\mathbf{3}}\right)$ & OPS $\left(\mathbf{k g} / \mathbf{m}^{\mathbf{3}}\right)$ & Mining sand $\left(\mathbf{k g} / \mathbf{m}^{3}\right)$ & Water $\left.\mathbf{( k g} / \mathbf{m}^{3}\right)$ & Silica fume $\left(\mathbf{k g} / \mathbf{m}^{\mathbf{3}}\right)$ & Steel fibres $\left(\mathbf{k g} / \mathbf{m}^{3}\right)$ \\
\hline HT0 & 530 & 320 & 970 & 170 & 50 & 0 \\
HT5 & 530 & 320 & 970 & 170 & 50 & 40 \\
HT10 & 530 & 320 & 970 & 170 & 50 & 80 \\
HT15 & 530 & 320 & 970 & 170 & 50 & 115 \\
HT20 & 530 & 320 & 970 & 170 & 50 & 155 \\
HT25 & 530 & 320 & 970 & 170 & 50 & 195 \\
HT30 & 530 & 320 & 970 & 170 & 50 & 235 \\
\hline
\end{tabular}

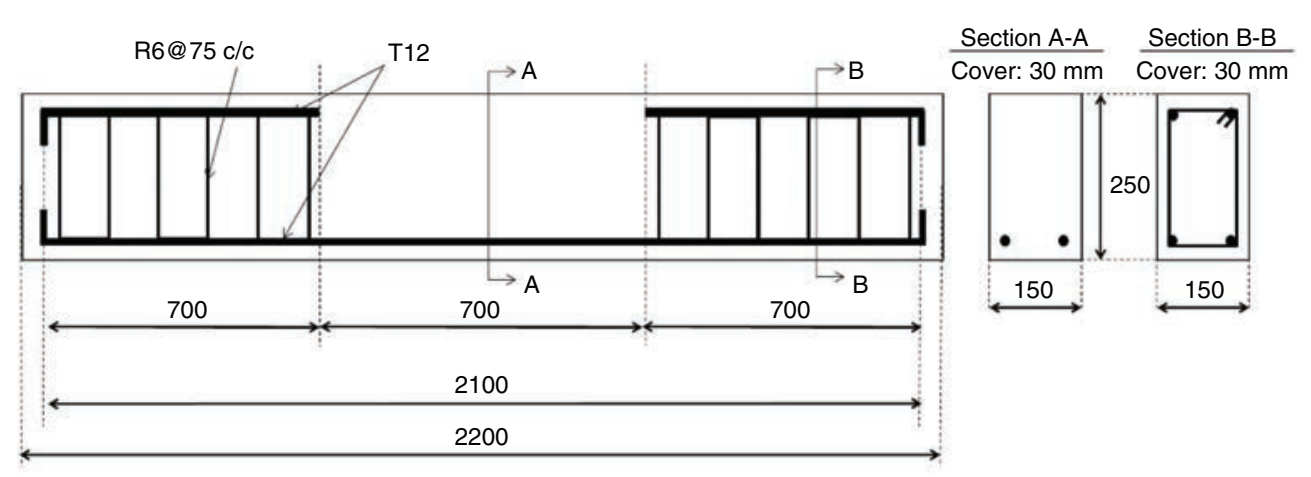

FigurE 2. Reinforcement details of flexure beams (all dimensions are in $\mathrm{mm}$ ).

tested for each mix design. Fig. 2 shows the reinforcement arrangement for all the flexural beams. Ribbed steel bars with diameter $12 \mathrm{~mm}$ were used as tension reinforcement for all the specimens with a clear cover of $30 \mathrm{~mm}$. The compression and shear reinforcements were not used in the middle-third of the beam (pure bending region-distance between two loading points is $0.7 \mathrm{~m}$ ). The shear reinforcement was used only in the shear span $(0.7 \mathrm{~m}$ from each support) at a spacing of about $75 \mathrm{~mm}$ centreto-centre to ensure yielding of tension steel before the crushing of concrete. The flexural testing of the beam specimens was conducted by using an Instron universal testing machine with a built-in load cell capacity of $600 \mathrm{kN}$ (Figure 3).

\section{RESULTS AND DISCUSSION}

\subsection{Mechanical properties}

The mechanical properties of OPSC and OPSFRC are reported in Table 3. Figure 4 shows that the 28-day compressive strength of OPSFRC increased proportionally with the addition of steel fibres; for an increase of $0.5 \%$ of steel fibres, the 28-day compressive strength of OPSFRC was enhanced by $2.4-5.3 \mathrm{MPa}(4-14 \%)$. The highest 28-day compressive strength of about $57 \mathrm{MPa}$ was reported in the HT30 mix, which was $63 \%$ higher than the OPSC mix. However, the fibre content cannot be further increased beyond 3\% due to the poor workability of fresh mixes with fibre content $>3 \%$. The compressive strength of HT10 mix is comparable to the published results of OPSFRC albeit with $1 \%$ steel fibres while the highest compressive strength of $57 \mathrm{MPa}$ was at least $15 \mathrm{MPa}$ higher (22).

The addition of steel fibres into conventional NWC generally did not impart any significant effect on the compressive strength $(30,31)$. Meanwhile previous studies on fibre-reinforced LWC have reported two different observations: (i) no effect and (ii) the addition of fibres resulted in a significant enhancement in the compressive strength of LWC, depending on the weak components of $\operatorname{LWC}(3,13,22,31,32)$. Such weak components of LWC include the porous, weak lightweight aggregates and the weak adhesion between aggregates and cement paste. The steel fibres produced negligible effect on the compressive strength of LWC made from low stiffness lightweight aggregates while the steel fibre reinforcement compensated the weak aggregate-cement paste bonding $(31,32)$. In the case of OPSC, the failure is governed by the weak bond strength between the cement paste and OPS (2). Under increasing compression loading, the vertical compressive strain and transverse tensile strain occur in the compressed concrete specimens. Hence, the continuous deformation of concrete produces cracks at the aggregate-cement 

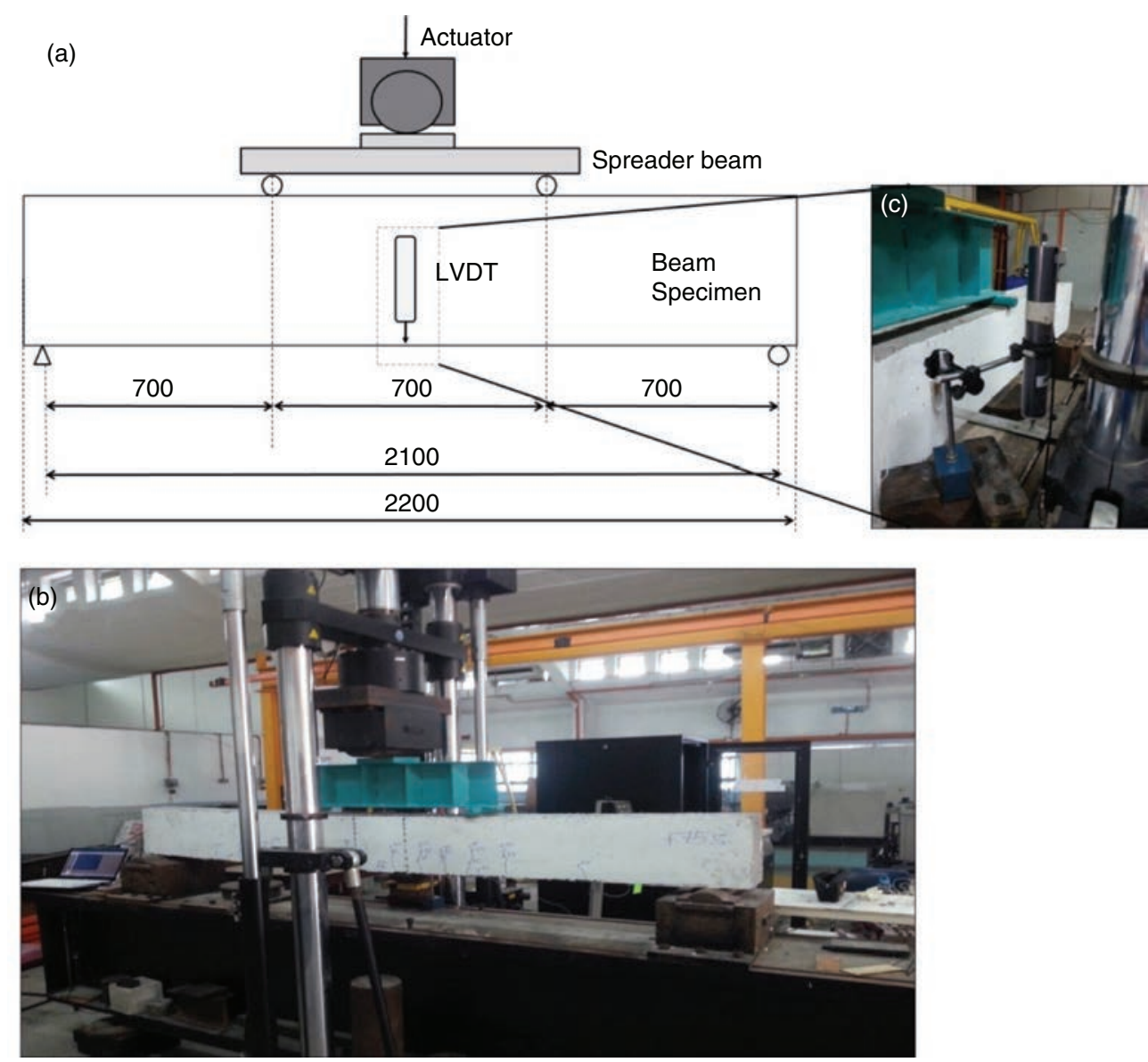

Figure 3. Flexural beam test setup (all dimensions are in $\mathrm{mm}$ ).

TABle 3. Mechanical properties

\begin{tabular}{|c|c|c|c|c|c|}
\hline Mix & $\begin{array}{c}\text { Compressive strength } \\
\text { (MPa) }\end{array}$ & $\begin{array}{l}\text { Splitting tensile } \\
\text { strength (MPa) }\end{array}$ & $\begin{array}{l}\text { Flexural strength } \\
\text { (MPa) }\end{array}$ & $\begin{array}{l}\text { Modulus of elasticity } \\
\text { (GPa) }\end{array}$ & Poisson's ratio \\
\hline \multirow[t]{2}{*}{ HT0 } & 34.8 & 3.22 & 4.84 & 13.53 & 0.255 \\
\hline & $(0.4)$ & $(0.03)$ & $(0.07)$ & $(0.19)$ & $(0.007)$ \\
\hline \multirow[t]{2}{*}{ HT5 } & 37.6 & 4.36 & 5.52 & 16.35 & 0.302 \\
\hline & $(0.7)$ & $(0.05)$ & $(0.07)$ & $(0.25)$ & $(0.012)$ \\
\hline \multirow[t]{2}{*}{ HT10 } & 42.9 & 5.85 & 8.29 & 16.01 & 0.297 \\
\hline & $(0.5)$ & $(0.02)$ & $(0.07)$ & $(0.29)$ & $(0.019)$ \\
\hline \multirow[t]{2}{*}{ HT15 } & 45.8 & 7.20 & 9.64 & 16.09 & 0.305 \\
\hline & $(0.5)$ & $(0.06)$ & $(0.05)$ & $(0.25)$ & $(0.022)$ \\
\hline \multirow[t]{2}{*}{ HT20 } & 49.3 & 7.94 & 10.95 & 15.79 & 0.317 \\
\hline & $(0.9)$ & $(0.10)$ & $(0.08)$ & $(0.19)$ & $(0.031)$ \\
\hline \multirow[t]{2}{*}{ HT25 } & 54.3 & 9.45 & 16.00 & 16.05 & 0.310 \\
\hline & $(1.0)$ & $(0.15)$ & $(0.17)$ & $(0.24)$ & $(0.025)$ \\
\hline \multirow[t]{2}{*}{ HT30 } & 56.7 & 10.99 & 18.48 & 15.62 & 0.291 \\
\hline & $(0.7)$ & $(0.12)$ & $(0.15)$ & $(0.33)$ & $(0.031)$ \\
\hline
\end{tabular}

Note: The standard deviations of the corresponding mechanical properties are shown in the brackets.

paste interface of OPSC (7). However, this weakness could be compensated by the addition of steel fibres. The additional fibre-matrix bond in the concrete increases the energy capacity of the concrete by the toughening mechanisms called fibre debonding and frictional sliding associated with fibre pullout $(33,34)$. 


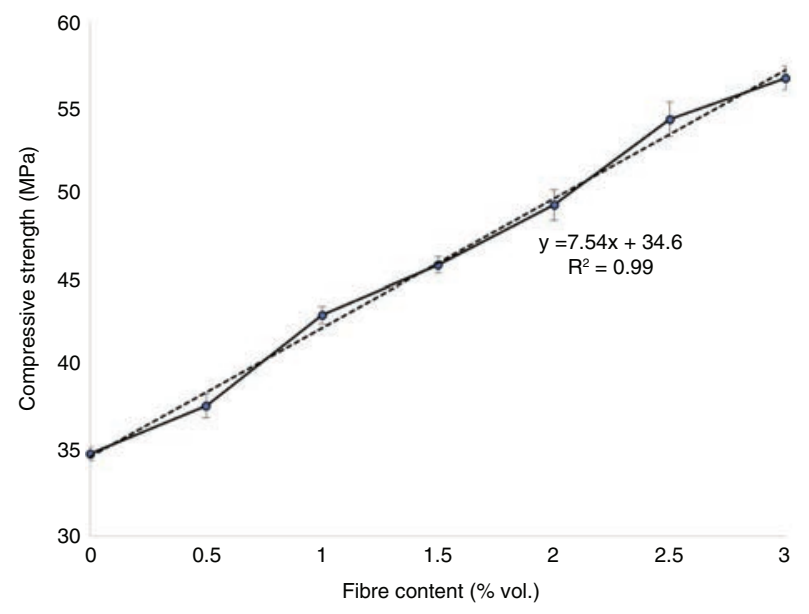

FIGURE 4. Graph of compressive strength versus steel fibre volume.

Furthermore, the steel fibres also arrest the crack opening; such an enhancement mechanism is generally known as the crack bridging effect $(13,17$, $19,20,33,34)$. The steel fibres bridge across the cracks in the concrete and take part or even all of the stress when subjected to increased loading. As the advancing crack reaches the fibres, the crack tip stress concentration is reduced, and, thus, the crack propagation is blunted and blocked. Therefore, both the fibre-matrix bond and crack bridging effect contributed to the significant enhancement of the compressive strength of OPSFRC.

In addition, the high amount of steel fibres added to the concrete increases the probability of its ability to be located in the vicinity between the OPS and the matrix thereby enhancing the bond. This explains the linear increment in the compressive strength of the OPSFRC when the volume fraction of the steel fibres increases.

In term of tensile strength, the control OPSC mix produced splitting tensile and flexural strengths of 3.2 $\mathrm{MPa}$ and 4.8 $\mathrm{MPa}$, respectively (Table 3). However, these values are relatively lower compared to the tensile strengths reported for NWC and other LWCs (34).

The addition of steel fibres by up to $3 \%$ drastically enhanced the tensile strength of OPSFRC by producing the highest splitting tensile and flexural strengths of 11.0 $\mathrm{MPa}$ and $18.5 \mathrm{MPa}$, respectively. This shows an enhancement of $240 \%$ and $285 \%$ compared to the splitting tensile and flexural strengths of the control mix. On the other hand, the HT30 mix produced a higher flexural strength $(>50 \%)$ than the fibre-reinforced NWC of the same density $\left(2400 \mathrm{~kg} / \mathrm{m}^{3}\right)(7,27)$. This has indicated the capability if the HT30 mix in compensating the weak tensile strength of conventional OPSC.

The enhanced tensile strength of OPSFRC could be explained similar to the compressive strength. The additional fibre-matrix bond and crack bridging effect of steel fibres allow the concrete to sustain higher tensile loading and to blunt the crack initiation and propagation. In addition, the steel fibres produce a greater improvement in the tensile strength than in the compressive strength of concrete. This statement is evident in the OPSFRC, as the OPSFRC reinforced with steel fibres yielded higher splitting tensile to compressive strength ratios and flexural to compressive strength ratios. The splitting tensile to compressive strength ratios of HT0, HT5, HT10, HT15, HT20, HT25 and HT30 were 9.2\%, 11.6\%, 13.6\%, $15.7 \%, 16.1 \%, 17.4 \%$ and $19.4 \%$, respectively; while the corresponding flexural to compressive strength ratios were $13.9 \%, 14.7 \%, 19.3 \%, 21.0 \%, 22.2 \%$, $29.5 \%$ and $32.6 \%$. Both ratios increased with the increment of fibre volume. The increased tensile to compressive strength ratios showed that the steel fibres produced higher enhancement effects in the OPSFRC compared to the compressive strength. This is attributed to concrete being generally weak in tension and that tensile cracks form at a much lower loading capacity before the ultimate compressive strength is reached. Therefore, under compression loading, the high compression capacity of steel fibre-reinforced concrete allows for a portion of the applied stress; however, under the tensile loading, the weak tensile strength of the concrete causes the concrete to only take up marginal applied stress. Hence, the contribution of steel fibres on the tensile strength of OPSFRC was more significant than the compressive strength.

The effects of steel fibres in LWC on the modulus of elasticity (MOE) and Poisson's ratio of LWC relies on the type of lightweight aggregate and fibre content (21). However, it should be noted that there is limited investigation on these aspects as far LWC is concerned. Referring to Table 3, the addition of steel fibres in OPSFRC enhanced the MOE by about 2-2.8 GPa (15-20\% increments). The organic OPS has a lower stiffness and restraining effect compared to granite aggregate. Hence, under compressive loading, the OPS undergoes higher strain compared to the NWC, and produces a lower MOE in OPSC (6). Hence the enhanced fibre-matrix bond enabled the OPSFRC to withstand higher compressive strain, while the crack bridging effect prevented and arrested the crack propagation, eventually resulting in the increased compressive energy capacity of OPSFRC. However, both the MOE and Poisson's ratio were found to be independent of the volume fraction of steel fibres. From the previous researches, it was shown that the addition of steel fibres increased both the compressive stress and strain. When fibre content is increased, both the compressive stress and strains improved equally $(36,37)$. This results in the MOE (slope of stressstrain curve) remains the same despite the fibre content increases. 
Similarly, the presence of steel fibres in the OPSFRC cement matrix arrested the crack propagation and the concrete was capable of enduring higher strain, in both the lateral and longitudinal directions. The benefit of steel fibres in enhancing the lateral strain was found to be more significant than the longitudinal strain. This is evident in the higher Poisson's ratio of OPSFRC, relative to the control OPSC (Table 3). The HT0 mix produced a Poisson's ratio of 0.255 , and then the Poisson's ratios of OPSFRC were improved to about 0.29-0.32 (14 $24 \%$ increments). Therefore, it can be concluded that the addition of steel fibres in OPSC enhanced both the MOE and Poisson's ratio.

\subsection{Flexural behaviours of reinforced concrete beams}

In this section the flexural behaviours of OPSC and OPSFRC reinforced concrete beams with the fibre volume of $1 \%$ and $3 \%$ are compared.

Fig. 5(a) shows the OPSC beams failed under concrete crushing at the compressive zone, while OPSFRC beams in Fig. 5(b and c) failed under bar fracture. Both the OPSFRC beams produced almost identical failure mode of failure, albeit HT30 beams produced smaller depth of flexural crack and concrete wedge. In fibre-reinforced concrete, the fibre improved the steel-concrete bonding by providing confinement effect which leads to the strain localization $(18,28)$. The strain localization can be explained by using Fig. 6. Fig. 6(b) showed the steel strains (shown as positive strain, while negative strains are denoted for concrete strains) of the steel reinforcement in OPSC specimen achieved maximum moment capacity at about 4500 microstrain $(\%)$, but the OPSFRC beams attained their respective maximum moments at about 2500-3000\%. The strain localization effect was more significant when the fibre content increases (29). The addition of high volume of steel fibres (3\% by volume) resulted in earlier bar fracture in HT30 beam (Fig. 5(c)) compared to HT10 beam (Fig. 4b) as the former failed under bar fracture before the full development of crack.

In addition, Fig. 7 shows the comparison of the moment-deflection curve of the beams and the results are summarized in Table 4.

The moment-deflection curve of HT30 mix shows distinct difference from the HT0 and HT10 beams. The incorporation of 3\% steel fibres improved the moment capacity of OPSFRC by about $40 \%$ relative to the OPSC beam. The improvement was about double as that of OPSFRC with 1\% steel fibres. The predicted ultimate moments of HT30 specimens using Eurocode, BS and ACI codes were 26.7, 23.9 and $25.1 \mathrm{kNm}$, respectively compared to the experimental ultimate moment of $38.6 \mathrm{kNm}$. The codes underestimate the moment capacity by $45-61 \%$ as these codes do not have provision for the design of fibre-reinforced LWC.

The studies on fibre-reinforced concrete reported that the addition of fibres produced both increment and reduction in the ductility $(26$,
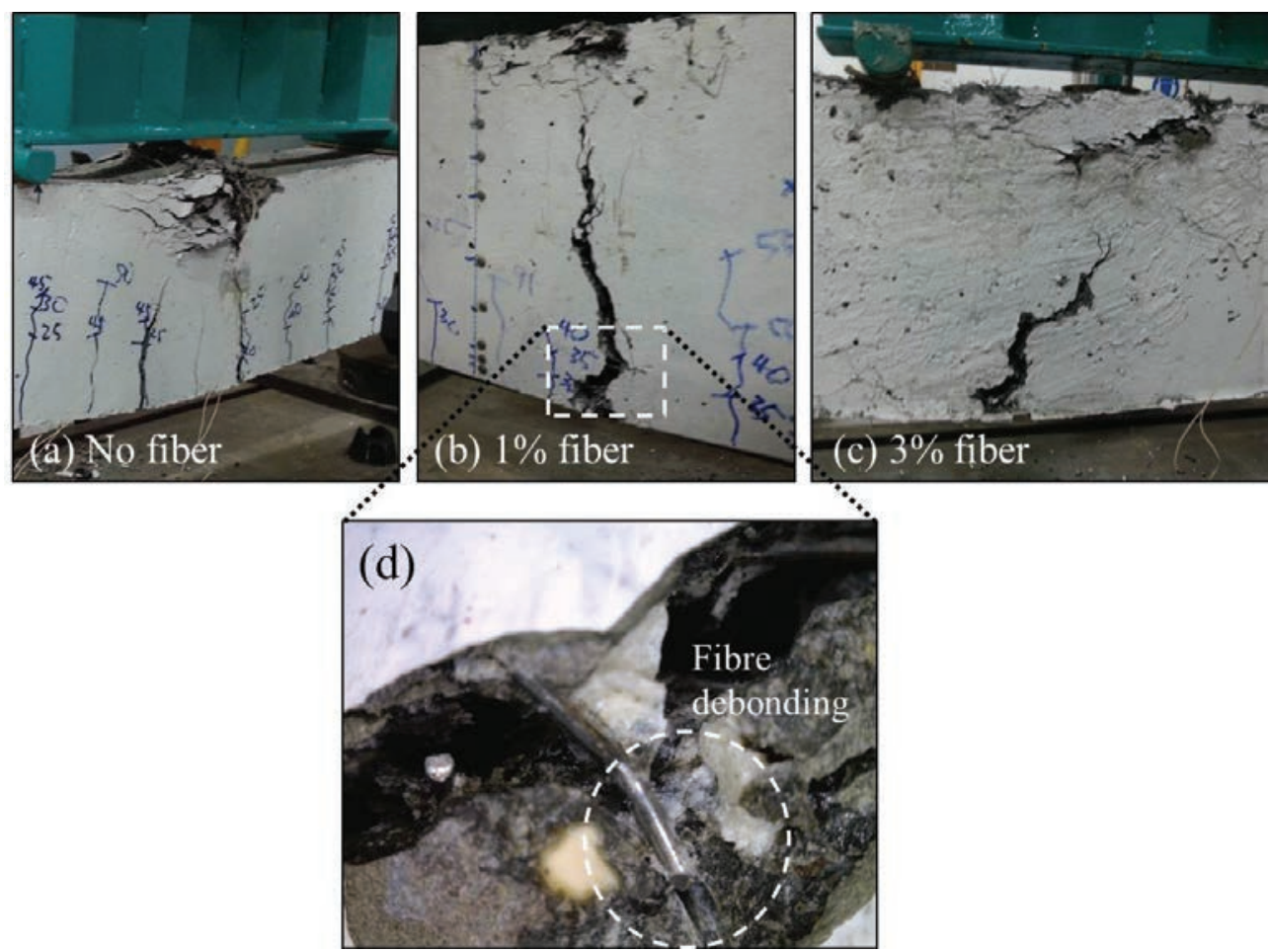

FIGURE 5. Comparison of mode of failure for OPSFRC beams with different fibre volume. 
28, 29). The latter effect was found applicable in OPSFRC beams. Based on the deflections at failure from Table 4, the HT10 and HT30 beams failed at deflection of 55.1 and $51.4 \mathrm{~mm}$, respectively. The values were $55-60 \%$ as that of OPSC beam. However, the difference between HT10 and HT30 beams differed by $4 \mathrm{~mm}$ only, but the difference between the OPSFRC and OPSC beams were $38-41 \mathrm{~mm}$. The reduced flexural ductility of OPSFRC beams opposed the observation in Section 4.4.3 that the addition of fibres enhanced the ductility of OPSFRC concrete prisms. In the reinforced OPSFRC beams, the strain localization effect is more dominant to decrease the flexural ductility. Despite the notable reduced deflection prior to failure in the OPSFRC beams, all beams satisfied the span to service deflection limit of 250 and 150 as stated in Eurocode and ASTM C1609, respectively. Hence the OPSFRC beams satisfied the deflection criteria of serviceability limit state as stipulated in Eurocode 2.

(a)

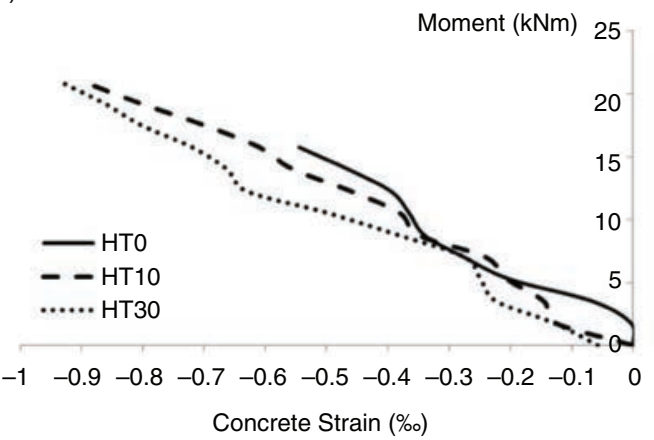

Another technique to measure the flexural ductility of a reinforced concrete beam is by ductility ratio. A high ductility ratio indicates that a structural member is capable of undergoing large deflections prior to failure (11). The mostly used ductility ratio is the deformation-based approach which is reflected by the deformation margin between the service and ultimate stages, as shown in Eq. [1] $(9,10,26)$.

$\mu=\delta_{\mathrm{f}} / \delta_{\mathrm{yld}}$

where $\mu=$ deformation-based ductility ratio, $\delta_{\mathrm{f}}=$ final mid-span deflection and $\delta_{\mathrm{yld}}=$ mid-span deflection when tensile steel yields.

Meanwhile Jaeger \& Tadros (38) introduced Eqs. 2-4 to take account for both the strength and deflection on the ductility characteristics [2].

$\mu_{2}=\mathrm{C}_{\mathrm{s}} \times \mathrm{C}_{\mathrm{d}}$

FIGURE 6. (a) Concrete and (b) steel strains for flexural beams.

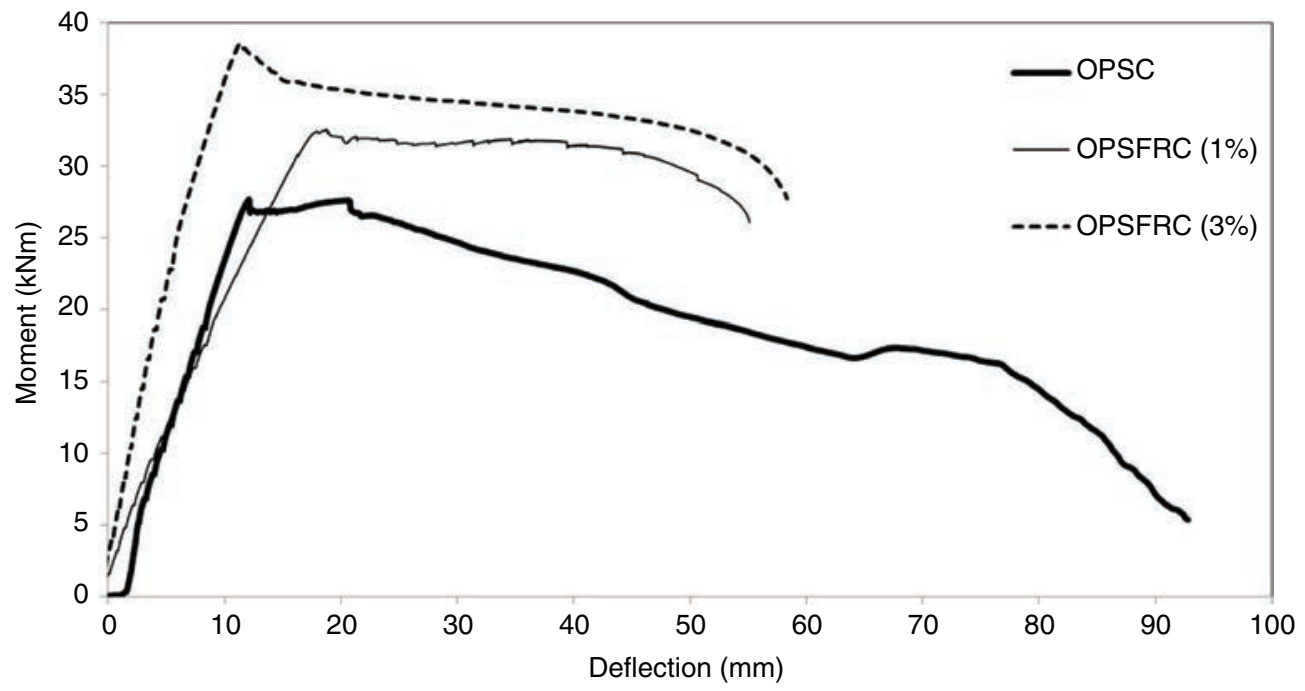

FIGURE 7. Moment-deflection curves of OPSC and OPSFRC reinforced beams. 
High strength oil palm shell concrete beams reinforced with steel fibres $\bullet 9$

TABLE 4. Comparison of the flexural behaviors and crack resistance of OPSC and OPSFRC beams

\begin{tabular}{llccccc}
\hline & Properties & HT0 & HT10 & $\begin{array}{c}\text { Ratio of } \\
\text { HT10/HT0 }\end{array}$ & $\begin{array}{c}\text { HT30 } \\
\text { HT30/HT0 }\end{array}$ \\
\hline \multirow{3}{*}{ Moment } & Experimental maximum moment $(\mathrm{kNm})$ & 27.7 & 32.6 & 1.18 & 38.6 & 1.39 \\
& Theoretical moment (Eurocode) $(\mathrm{kNm})$ & 25.1 & 26.2 & 1.04 & 26.6 & 1.06 \\
& Theoretical moment $(\mathrm{BS})(\mathrm{kNm})$ & 26.3 & 23.6 & 0.90 & 24.9 & 0.95 \\
& Theoretical moment $(\mathrm{ACI})(\mathrm{kNm})$ & 26.7 & 23.9 & 0.90 & 25.1 & 0.94 \\
\multirow{5}{*}{ Deflection } & Deflection at failure $(\mathrm{mm})$ & 92.8 & 55.1 & 0.60 & 51.4 & 0.55 \\
& Span to service deflection ratio & 22.6 & 38.1 & 1.68 & 40.8 & 1.80 \\
& Ductility ratio, $\mu$ & 11.43 & 5.58 & 0.50 & 6.47 & 0.56 \\
& Ductility ratio, $\mu_{2}$ & 8.51 & 9.75 & 1.15 & 9.03 & 1.06 \\
& Primary crack width at service load $(\mathrm{mm})$ & 0.16 & 0.11 & 0.69 & 0.09 & 0.56 \\
& Spacing between primary cracks $(\mathrm{mm})$ & 165 & 115 & 0.70 & 105 & 0.63 \\
\hline
\end{tabular}

where $\mu_{2}=$ ductility ratio by Jaeger, Tadros and Mufti (1997), $\mathrm{C}_{\mathrm{s}}=$ strength factor calculated from Eq. [3] and $\mathrm{C}_{\mathrm{d}}=$ deflection factor calculated from Eq. [4].

$\mathrm{C}_{\mathrm{s}}=\mathrm{M}_{\mathrm{u}} / \mathrm{M}_{\varepsilon} 0.001$

$\mathrm{C}_{\mathrm{d}}=\delta_{\mathrm{u}} / \delta_{\varepsilon 0.001}$

where $\mathbf{M}_{\mathrm{u}}=$ moment capacity, $\mathbf{M}_{\varepsilon 0.001}=$ moment when tensile steel strain is $0.001, \delta_{\mathrm{u}}=$ mid-span deflection at moment capacity and $\delta_{\varepsilon 0.001}=$ midspan deflection when tensile steel strain is 0.001 .

The ductility ratios, $\mu$ and $\mu_{2}$ for OPSC and OPSFRC beams are reported in Table 4. Members with ductility ratio in the range of 3 to 5 have adequate ductility and can be considered for structural members subjected to large displacements, such as sudden forces caused by earthquake (39). The OPSC beams produced ductility ratio $\mu$ of 11.4 and this showed that OPSC is a ductile material attributed to its low modulus of elasticity. Moreover, the observations on the reduced flexural ductility in OPSFRC beams are reflected in the ductility ratio $\mu$. Both the HT10 and HT30 beams produced $\mu$ of 5.6 and 6.5 , respectively and the values are about $50-55 \%$ of that OPSC. Despite that, the ductility ratios are wellabove of the required values for structural members. Moreover, the effect of increasing volume fraction on the ductility ratio is less significant as both the ductility ratio $\mu$ of OPSFRC with $1 \%$ and $3 \%$ are close to each other. This phenomenon could be called as "ceiling effect" as described by other researcher (13).

Meanwhile the ductility ratio $\mu$ which consider only the deflection margin between the final and yield stages is not appropriate to demonstrate the effect of steel fibres on the flexural behaviours of OPSFRC beams. Previous discussions mentioned that the fibre-matrix bond improved the moment capacity but accompanied by early steel bar fracture. Therefore ductility ratio, $\mu_{2}$ is more appropriate for the OPSFRC specimens as it takes account for both strength and deflection criteria. Based on Table 4, the steel fibre produced 6-15\% higher values of $\mu_{2}$ than the OPSC beam. This showed that the steel fibres compensated the reduced deflection by imparting higher increment in the moment capacity of the OPSFRC specimens.

Fig. 8 shows the comparison of the crack patterns of OPSC and OPSFRC with $1 \%$ and $3 \%$ steel fibres. The HT30 beam (Fig. 8(c)) showed excellent crack arresting ability by exhibiting smaller number of flexural cracks and the depth and width of the cracks are notably reduced compared to the OPSC and HT10 beams. In addition, the crack width of the primary crack at service load in HT10 and HT30 beam was 0.11 and $0.09 \mathrm{~mm}$, respectively. The crack widths were about $30-40 \%$ lower than the OPSC beam $(0.16 \mathrm{~mm})$ and the crack widths are only onethird of the maximum crack width limit stated in BS $8110(0.3 \mathrm{~mm})$. Hence it can be concluded that the OPSFRC with steel fibre up to $3 \%$ fulfilled the requirement for the serviceability limit state for cracking control. Furthermore, the crack spacing between the primary cracks for HT30 beam was reduced to $105 \mathrm{~mm}$ compared to 165 and $115 \mathrm{~mm}$, in OPSC and HT10 mixes, respectively. Finally, the steel fibres delayed the crack formation in OPSFRC beams with enhanced the crack resistance of OPSFRC. The first and secondary cracks of HT30 beams were initiated at 55 and $85 \mathrm{kN}$, respectively; while the corresponding first and secondary cracking OPSC are 12.5 and $40 \mathrm{kN}$ only. The increments of for first and secondary cracks in HT30 specimens are $340 \%$ and $110 \%$, respectively relative to the control OPSC. The enhanced crack resistance of OPSFRC beams can be explained by the crack bridging effect as shown in Fig. 5. Fig. 5(b and c) showed the presence of steel fibre across the primary crack of OPSFRC beams blunted and changed the direction of the crack propagation, eventually delayed the crack formation and increased the cracking load. As the crack tip stress exceeded the 

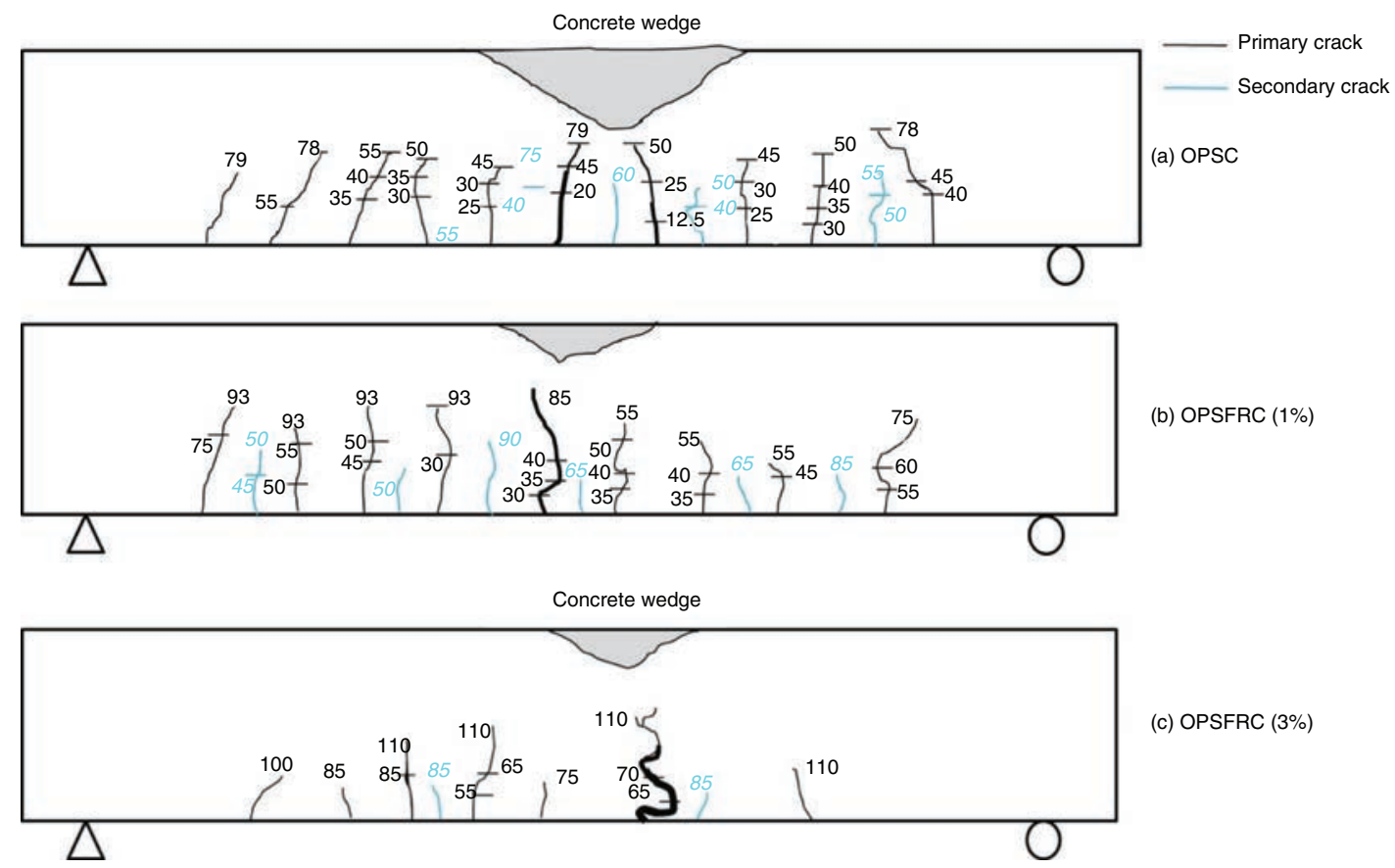

FIGURE 8. Crack patterns of OPSC and OPSFRC beams at ultimate moment (numbers in figures denote load in kN).

fibre-matrix interfacial bond, fibre debonding took place (Fig. 5d) and reduced the crack opening. In summary, the excellent crack resistance of OPSFRC beam with steel fibre up to $3 \%$ outperformed the OPSC with significant reduced crack spacing, crack width and depth and improved crack load capacity.

\section{CONCLUSIONS}

In general, the addition of steel fibres in OPSC enhances the mechanical properties and flexural behaviours. This is the maiden attempt concerning the addition of a high volume of steel fibres in OPSC, and, hence, the findings are significant. Based on the parameters investigated, the following conclusions can be drawn:

1. The addition of steel fibre up to $3 \%$ by volume improved the mechanical properties of OPSFRC mixes. The highest compressive, splitting tensile and flexural strengths of 57, 11.0 and 18.5 $\mathrm{MPa}$, respectively were reported for the HT30 mix reinforced with $3 \%$ steel fibres. The corresponding increments relative to the control mix are $63 \%, 240 \%$ and $285 \%$, respectively.

2. The OPSFRC reinforced concrete beams with steel fibres up to $3 \%$ showed distinct improvements in the flexural behaviours compared to the OPSC beams. The moment capacity of HT30 beams are 40\% higher than the OPSC.

3. The strain localization effect results in early bar fracture and $40-45 \%$ reduction in the final deflection in both HT10 and HT30 beams.
Despite that, both OPSC and OPSFRC beams satisfied the span to service deflection limit as stipulated in Eurocode and ASTM C1609.

4. The crack bridging effect of steel fibres blunts, changes the direction of crack propagation and reduces crack opening for the beams under flexural loading, eventually improves the crack resistance of OPSFRC beams significantly.

\section{ACKNOWLEDGEMENTS}

This study was funded by University of Malaya under Bantuan Kecil Penyelidikan (BKP) titled "Development of waterproofing cement mortar using plastic filling" (Project Number: BK004-2016).

\section{REFERENCES}

1. Kivrak, S.; Tuncan, M.; Onur, M.I.; Arslan, G.; Arioz, O. (2006). An economic perspective opf advantages of using lightweight concrete in construction, Proceeding of 31st Conference on Our World In Concrete \& Structures, Singapore.

2. Yap, S.P.; Alengaram, U.J.; Jumaat, M.Z. (2013). Enhancement of mechanical properties in polypropylene- and nylon-fibre reinforced oil palm shell concrete. Mater. Des. 49, 1034-1041. https://doi.org/10.1016/j. matdes.2013.02.070

3. Campione, G.; Miraglia, N.; Papia, M. (2001). Mechanical properties of steel fibre reinforced lightweight concrete with pumice stone or expanded clay aggregates, Mater. Struct. 34[4], 201-210. https://doi.org/10.1007/BF02480589

4. Short, A.; Kinniburgh, W. (1978). Lightweight concrete, C.R. Books 1978 .

5. Wu, C.; Oehlers, D.J.; Rebentrost, M.; Leach, J.; Whittaker, A.S. (2009). Blast testing of ultra-high performance fibre and FRP-retrofitted concrete slabs. Eng. Struct. 31[9], 2060-2069. https://doi.org/10.1016/j.engstruct.2009.03.020 
6. Alengaram, U.J.; Mahmud, H.; Jumaat, M.Z. (2011). Enhancement and prediction of modulus of elasticity of palm kernel shell concrete. Mater. Des. 32[4], 2143-2148. https://doi.org/10.1016/j.matdes.2010.11.035

7. Balendran, R.V.; Zhou, F.P.; Nadeem, A.; Leung, A.Y.T. (2002). Influence of steel fibres on strength and ductility of normal and lightweight high strength concrete. Build. Environ. 37[12], 1361-1367. https://doi.org/10.1016/ S0360-1323(01)00109-3

8. Klein, N.S.; Fuente, A.D.L.; Aguado, A.; Masó, D. (2011). Lightweight self-compacting concrete reinforced with fibres for slab rehabilitation. Mater. Construcc. 61[302], 239-256. https://doi.org/10.3989/mc.2011.55509

9. Alengaram, U.J.; Muhit, B.A.A.; Jumaat, M.Z. (2013). Utilization of oil palm kernel shell as lightweight aggregate in concrete - A review. Construct. Build. Mat. 38, 161-172. https://doi.org/10.1016/j.conbuildmat.2012.08.026

10. Mannan, M.A.; Ganapathy, C. (2001). Long-term strengths of concrete with oil palm shell as coarse aggregate. Cem. Concr. Res. 31[9], 1319-1321. https://doi.org/10.1016/ S0008-8846(01)00584-1

11. Teo, D.C.L.; Mannan, M.A.; Kurian, V.J. (2006). Flexural behaviour of reinforced lightweight concrete beams made with oil palm shell (OPS). J. Adv. Concr. Technol. 4[3], 459-468. https://doi.org/10.3151/jact.4.459

12. Alengaram, U.J.; Jumaat, M.Z.; Mahmud, H. (2008). Ductility behaviour of reinforced palm kernel shell concrete beams. Eur. J. Sci. Res. 23[3], 406-420.

13. Gao, J.; Sun, W.; Morino, K. (1997). Mechanical properties of steel fibre-reinforced, high-strength, lightweight concrete. Cem. Concr. Comp. 19, 307-313. https://doi. org/10.1016/S0958-9465(97)00023-1

14. Bian, H. Hannawi, K - Takarli, M ; Molez, L. Prince, W. (2016). Effects of thermal damage on physical properties and cracking behaviour of ultrahigh-performance fibrereinforced concrete. J. Mater. Sci. 51[22], 10066-10076. https://doi.org/10.1007/s10853-016-0233-9

15. Tonoli, G.H.D.; Pizzol, V.D.; Urrea, G.; Santos, S.F.; Mendes, L.M.; Santos, V.; John, V.M.; Frías, M.; Savastano, H. (2016). Rationalizing the impact of aging on fibre-matrix interface and stability of cement-based composites submitted to carbonation at early ages. J. Mater. Sci. 51[17], 7929-7943. https://doi.org/10.1007/ s10853-016-0060-z

16. Afroughsabet, V.; Biolzi, L.; Ozbakkaloglu, T. (2016). High-performance fibre-reinforced concrete: a review. J. Mater. Sci. 51[14], 6517-6551. https://doi.org/10.1007/ s10853-016-9917-4

17. Savastano Jr, H.; Santos, S.F.; Tonoli, G.H.D.; Mejia, JE.B.; Fiorelli, J. (2015). Non-conventional cement-based composites reinforced with vegetable fibres: A review of strategies to improve durability. Mater. Construcc. 65[317], e041. https://doi.org/10.3989/mc.2015.05514

18. González-García, M.N.; Fernández-Cánovas, M.; Piñero, J.Á.; Cobo, A. (2016). Compressive strength behaviour of low- and medium-strength concrete specimens confined with carbon fibres in defective implementation conditions: an experimental study. Mater. Construcc. 66[324], e103. https://doi.org/10.3989/mc.2016.08315

19. Buratti, N.; Mazzotti, C.; Savoia, M. (2011). Post-cracking behaviour of steel and macro-synthetic fibre-reinforced concretes. Construct. Build. Mat. 25, 2713-2722. https:// doi.org/10.1016/j.conbuildmat.2010.12.022

20. Ng, T.S.; Foster, S.J.; Htet, M.L.; Htut, T.N.S. (2013). Mixed mode fracture behaviour of steel fibre reinforced concrete. Mater. Struct. 47[1-2], 67-76. https://doi.org/10.1617/ s11527-013-0045-1

21. Altun, F.; Aktaş, B. (2013). Investigation of reinforced concrete beams behaviour of steel fibre added lightweight concrete. Construct. Build. Mat. 38, 575-581. https://doi. org/10.1016/j.conbuildmat.2012.09.022

22. Shafigh, P.; Mahmud, H.; Jumaat, M.Z. (2011). Effect of steel fibre on the mechanical properties of oil palm shell lightweight concrete. Mater. Des. 32[7], 3926-3932. https:// doi.org/10.1016/j.matdes.2011.02.055
23. Mo, K.H.; Yap, S.P.; Alengaram, U.J.; Jumaat, M.Z.; Bu, C.H. (2014). Impact resistance of hybrid fibre-reinforced oil palm shell concrete. Construct. Build. Mat. 50, 499-507. https://doi.org/10.1016/j.conbuildmat.2013.10.016

24. Yap, S.P.; Alengaram, U.J.; Jumaat, M.Z. (2016). The effect of aspect ratio and volume fraction on mechanical properties of steel fibre-reinforced oil palm shell concrete. J. Civ. Eng. Manag. 22[2], 168-177. https://doi.org/10.3846/13923 730.2014 .897970

25. Gribniak, V.; Kaklauskas, G.; Hung Kwan, A.K.; Bacinskas, D.; Ulbinas, D. (2012). Deriving stress-strain relationships for steel fibre concrete in tension from tests of beams with ordinary reinforcement. Eng. Struct. 42, 387-395. https:// doi.org/10.1016/j.engstruct.2012.04.032

26. Qian, C.; Indubhushan, P. (1999). Properties of highstrength steel fibre-reinforced concrete beams in bending. Cem. Concr. Comp. 21[1], 73-81. https://doi.org/10.1016/ S0958-9465(98)00040-7

27. Altun, F.; Haktanir, T.; Ari, K. (2007). Effects of steel fibre addition on mechanical properties of concrete and RC beams. Construct. Build. Mat. 21[3], 654-661. https://doi. org/10.1016/j.conbuildmat.2005.12.006

28. Wang, H.; Belarbi, A. (2011). Ductility characteristics of fibre-reinforced-concrete beams reinforced with FRP rebars. Construct. Build. Mat. 25[5], 2391-2401. https://doi. org/10.1016/j.conbuildmat.2010.11.040

29. Meda, A.; Minelli, F.; Plizzari, G.A. (2012). Flexural behaviour of RC beams in fibre reinforced concrete. Compos. Part B-Eng. 43[8], 2930-2937. https://doi.org/10.1016/j. compositesb.2012.06.003

30. Bencardino, F.; Rizzuti, L.; Spadea, G.; Swamy, R.N. (2008). Stress-strain behavior of steel fiber-reinforced concrete in compression. J. Mater. Civil. Eng. 20[3], 255-263. https://doi.org/10.1061/(ASCE)0899-1561(2008)20:3(255)

31. Hassanpour, M.; Shafigh, P.; Mahmud, H. (2012). Lightweight aggregate concrete fiber reinforcement - A review. Construct. Build. Mat. 37, 452-461. https://doi. org/10.1016/j.conbuildmat.2012.07.071

32. Domagala, L. (2011). Modification of properties of structural lightweight concrete with steel fibres. J. Civ. Eng. Manag. 17[1], 36-44. https://doi.org/10.3846/13923730.20 11.553923

33. Singh, S.; Shukla, A.; Brown, R. (2004). Pullout behaviour of polypropylene fibres from cementitious matrix. Cem. Concr. Res. 34[10], 1919-1925. https://doi.org/10.1016/j. cemconres.2004.02.014

34. Blanco, A.; Pujadas, P.;Fuente, A.D.L.; Cavalaro, S.H.P.; Aguado, A. (2016). Influence of the type of fiber on the structural response and design of FRC slabs. $J$. Struct. Eng. 142[9], https://doi.org/10.1061/(ASCE) ST.1943-541X.0001515

35. Chen, B.; Liu, J. (2005). Contribution of hybrid fibres on the properties of the high-strength lightweight concrete having good workability. Cem. Concr. Res. 35[5], 913-917. https://doi.org/10.1016/j.cemconres.2004. 07.035

36. Yap, S.P.; Alengaram, U.J.; Jumaat, M.Z.; Khaw, K.R. (2016). Torsional and cracking characteristics of steel fibre-reinforced oil palm shell lightweight concrete. J. Compos. Mater. 5[1], 115-128. https://doi. org/10.1177/0021998315571431

37. Yap, S.P.; Alengaram, U.J.; Jumaat, M.Z.; Khaw, K.R. (2015). Torsional behaviour of steel fibre-reinforced oil palm shell concrete beams. Mater. Des. 87, 854-862. https:// doi.org/10.1016/j.matdes.2015.08.078

38. Jaeger, G.L.; Tadros, G.; Mufti, A.A. (1997). The concept of the overall performance factor in rectangularsection reinforced concrete beams, Proceeding of 3rd International Symposium on Non-metallic (FRP) reinforcement for concrete structures, Sapporo, Japan, 1997, pp. $551-558$.

39. Ashour, S.A. (2000). Effect of compressive strength and tensile reinforcement ratio on flexural behaviour of highstrength concrete beams. Eng. Struct. 22[5], 413-423. https://doi.org/10.1016/S0141-0296(98)00135-7 